\title{
KONFIGURASI DAN TRANSFORMASI KEHIDUPAN AGAMA DI KECAMATAN BALIKPAPAN TIMUR KOTAMADYA BALIKPAPAN PROPINSI KALIMANTAN TIMUR
}

\author{
Oleh : Ahmad Syafi'i
}

\section{PENDAHULUAN}

\subsection{Beberapa temuan}

Tujuan pcnclitian, sebagaimana dirumuskan dalam kerangka acuan adalah untuk : Pertama, mengctahui fungsi dan pcranan aparat Dcpartcmcn Agama di tingkat bawah dalam mcmbcrikan pclayanan dan bimbingan agama. Kcdua, mengctahui bagaimana pcrgcseran-pcrgeseran nilai agama dan kc arah mana pcrgcseran tersebut, guna pcnyusunan konscp bimbingan agama (dakwah) yang adaplip terhadap perkcmbangan sosial budaya. Kctiga, mcmahami proses akulturasi dan sosialisasi agama untuk membcri masukan bagi pembaruan sistem pendidikan dan pengajaran agama. Keempat, dengan mencliti lckturlektur agama yang hidup dan diminati masyarakat maka diharapkan dapat disusun pola bimbingan agama melalui "kelekturan kontcmporer" sesuai dengan kemauan masyarakat dan pcrkembangan tcknologi komunikasi.

Beberapa temuan yang perlu diketengahkan berkaitan dengan tujuan pcnclitian adalah sebagai bcrikut:

1.1.1 Aparat Departcmen Agamadi Kccamatan ini melipuli Kantor Urusan Agama (KUA) dan Pcmilik Pendidikan Agama (PPA) Dalam kailannya dengan bimbingan dan pclayanan agama, KUA tidak hanya mcnjalankan tugas dan fungsi sebagaimana diatur dalam KUA No. 18/1975 pasal 729 dan pasal 730, yakni sebagai pelaksana scbagian tugas Kantor Dcpartemen Agama Kabupaten/Kotamadya di bidang urusan Agama Islam, tetapi karcna tuntutan perubahan, KUA telah berfungsi sebagai Kantor Departemen Agama tingkat Kecamatan. Sebaliknya, PPA mengalami berbagai kendala karcna pcrbandingan antara tenaga dan fasilitas tidak imbang. Pejabat pada instansi ini hanya scorang tanpa staf, sedang bidang tugas dan tanggungjawab kcpcnilikannya meliputi 117 buah sekolah Dasar dan Madrasah Ibtidaiyah.

1.1.2. Kcpcmimpinan dan organisasi keagamaan di dacrah ini mcnunjukkan gejala pergeseran ke arah semakin majemuk. Jika pada masa lalu, sebclum tahun 1980an, kcpcmimpinan agama pada tingkat desa tcrpusat pada pcranan Imam, kemudian dukun maka dewasa ini telah terjadi keragaman kepemimpinan yang didasarkan atas faham keagamaan, administrasi pemerintahan dan juga organisasi keagamaan.

1.1.3. Masuknya faham baru (kaum muda) ternyata berpengaruh pada penyelenggaran pendidikan agama dalam masyarakat. Masyarakat kclurahan Tritip dan Lamaru cenderung mencrima kehadiran madrasah, sedang masyarakat kclurahan Manggar Lama dan Manggar baru justru semakin mcnunjukkan gejala enggan menyekolahkan 
anak-anak mereka ke madrasah. Sementara itu pendidikan agama Islam di SD kurang dapat diandalkan hasilnya. Oleh karena itu perhatian orang tua dan kepeduliannya terhadap pendidikan agama di dalam keluarga dan masyarakat masih kuat terutama untuk pengajian Al Qur'an. Bahkan oleh pihak pejabat agama, masyarakat telah digerakkan untuk mendirikan Taman pendidikan $\mathrm{Al}$ Qur'an (TPA) dengan menggunakan metode Iqra' pada setiap masjid atau surau dengan dukungan dana APBD.

1.1.4. Dakwah yang diselenggarakan ada dua macam berdasarkan faham yaitu faham "Kaum muda" dan "Kaum Tua". Sasaran dakwah kaum muda diarahkan pada para pemuda dan remaja dengan metode diskusi. Materi dakwah yang disajikan juga cenderung bersifat pemurnian ajaran agama dan mendorong sikap hidup mandiri dan kerja keras. "Kaum Tua" dalam penyelenggaraan dakwah masih tetap terkait dengan perayaan hari-hari besar Islam dengan mendatangkan mubalig dari luar kelurahan Setiap perayaan ini seringkali disertai dengan pembacaan Barzanji atau selawat.

1.1.5. Perubahan-perubahan dalam berbagai bidang kehidupan, terutama dengan munculnya faham keagamaan baru, lckturkeagamaan juga mengalami perkembangan. Pada tingkat pemimpin agama, buku yang dimiliki atau dibaca sebagian besar adalah kitab fiqih, tauhid dan tasawuf yang berbahasa Melayu atau kitab terjemahan bagi kaum tua, sedang untuk kaum muda bacaan atau lektur keagamaan yang dimiliki sangat luas dan dalam berbagai bahasa, termasuk dalam bahasa Inggris. Kendatipun telah terjadi perkembangan lektur pada lapis pemimpin, lektur agama pada lapisan masyarakat awam masih tetap yaitu Al Qur'an, Berzanji, Yasin dan buku-buku doa.

1.1.6. Bimbingandanpelayanankeagamaan yang telah dilakukan oleh pemimpin agama : KUA meliputi penyuluhan mengenai perkawinan (UUP no 1/1974 ) ; Zawaib (PP 28/1877) kerukunan beragama bail intern maupun antardan peningkatan kualitas kcimanan dan ketakwaan. Pelayanan yang deiberikan terutama berkaitan dengan NCTR, bantuan pelayanan masalahmasalah sosial keagamaan seperti penyiaran agama dan pendirian rumah ibadah, konsultasi perkawinan, percarcaian, keluarga sejehtera dan pendistribusian zakat, pembuatan akte wakaf dan sebagainya. PPA juga telah mcncoba memberikan bimbimbingan dan pelayanan berupa pcnataran guru agama. Bcgitu juga penyuluh Agama Honorer ( PAH ), pemimpin organisasi keagamaan dan Imam telah memberikan bimbingan pelayanan.

\subsection{Kerangka Konseptual}

Konfigurasi seperti dinyatakan oleh Spradley dan MC. Curdy (1975 : 456 - 457 ) ialah pattern of interrelationships among all the major elemens of Culture. Konfigurasi sebuah kebudayaan merupakan pola kcbudayaan yang asli. Pola kebudayaan tersebut berfungsi sebagai alat penyeleksi bagi unsur - unsur kebudayaan baru yang masuk (Benedict, 1959:327 ). Konfigurasi kebudayaan dapat dikatakan sebagai nyawa atau jiwa dari kebudayaan tersebut dan konfigurasi biasanyaterdiri atas seperangkat kecenderungan-kecenderungan yang nampak ada dan berlaku terus menerus se- 
bagaimana yang terwujud dan merupakan abstaksi dari keseluruhan aspek kehidupan dalam suatu masyarakat, dan secara erat berkaitan antara satu dengan lainnya dan yang memberi serta menghasilkan terwujudnya kesatuan intergratif dalam kebudayaan tersebut (Supelan, $1986: 13$ ).

Konfigurasi kehidupan keagamaan dengan demikian dapat diartikan kecenderungan - kecenderungan atau pola pola kelakuan dan tindakan para penganut suatu agama yang berkaitan dengan keyakinan yang dimiliki oleh masing masing indivisu sebagai anggota suatu komuniti keagamaan ( Umat).

Keyakinan yang dijadikan acuan dalam bertindak tersebut bersumber dari ajaran agama dan adakalanya juga berkaitan dengan kebudayaan atau keyakinan lain yang telah dianggap sebagai keyakinan scndiri dan dianggap tidak bertentangan dengan ajaran agamanya yang asli. Dengan demikian, keyakinan keagamaan yang dijadikan dasar tindakan seorang penganut suatu agamatentu sajadapatbersumbcrdari informasi atau petuhjuk yang berasal dari ajaran agama sendiri dan dapatjuga berasal dari ajaran agama sendiri dan dapat juga berasal dari luar ajaran agamanya, tctapi tidak bertentangan dengan ajaran agama yang dianut.

Ajaran-ajaran tersebut dapat diperoleh melalui usaha pemahaman sendiri terhadap teks agama maupun melalui sosialisasi dan enkulturasi. Ketcrikatan warga masyarakat terhadap ajaran atau keyakinan yang bersumber dari teks suci atau teks lainnya yang digali secara langsung, maupun melalui pcrantaraan lembaga-lembaga, orang tua, guru, kyai, pej abat agama dan pemuka agam a lainnya, dalam organisasi sekolah, majlis taklim, tempat ibadah adalah dasar dari sebuah konfigurasi. Kehidupan beragama dapat dilihat pada keterpaduan tindakan keagamaan dengan ajaran agama dalam sebuah komuniti pada waktu tertentu.

Komuniti, atau masyarakat dan kebudayaannya dalam kenyataannya tidak statis. Perubahan-perubahan dapat saja terjadi baik secara cepat (revolusi) maupun secara perlahan lahan (evalusi). Ciri Involusi "tumbuh ke dalam, bukan mekar dan mengubah diri, oleh Geertz digambarkan telah menjalarpadabidang-bidanglain; pada pelapisan masyarakat di desa, hubungan keluarga, bahkan pada pola kepercayaan (Sajogya, 1983 : XXVIII). Masyarakat dan kebudayaan dilihat dari sebuah sistem dapat berubah disebabkan oleh pengaruh lingkungan, perkembangan penduduk, inovasi, difusi, akulturasi, modernisasi, urbanisasi dan karcna psikolultural (Spindlcr, 1984). Kendatipun demikian, tidak ada kelompok sosial yang berubah secara cepat bila perubahan hanya datang dari anggotaanggotanyasendiri (Foster, 1973:16). Kctika sebuah proses pcrubahan berjalan, dimana aturan-aturan baru belum mapan, karena belum diterimanya nilai-nilai baru oleh warga masyarakat, maka yang terjadi adalah pergeseran-pergeseran nilai yang dapat saja mcnyebabkan kctidaktcraturan (anomie), ketegangan (aleinasi) dan kontradiksi (Kuntowijoyo, 1987:9-23).

Kehidupan agama baik dilihat dari aspek ajaran maupun pengamalannya seringkali mengalami pcrubahan. Perubahan ajaran agama pada dasarnya tidak akan pernah 
ada, tetapi penafsiran terhadap ajaran agama itu senantiasa berubah. Karena perubahan penafsiran maka pengalaman agama juga mengalami perubahan. Perubahan dalam penafsiran dan pengalaman agama inilah yang disebut transformasi kehidupan agama. Bertolak dari pandangan ini maka kehidupan agama merupakan subsistem dari sebuah sistem sosial budaya sebuah komuniti dimana antara subsistem yang satu dengan yang lain merupakan satu kesatuan yang menyeluruh. Cara pandang yang demikian melahirkan implikasi metodologi penelitian yang bcrsifat kualitatif dengan mengandalkan pada pengamatan lapangan disamping metode lainnya.

\subsection{Penelitian di Lapangan.}

Pendekatan kualitatif yangdipergunakan dalam melihatkonfigurasi dan transformasi kehidupan agama menuntun peneliti untuk Hidup bersama masyarakat yang diteliti, yakni masyarakat Balikpapan Timur. Pemilihanlokasi penelitian merupakan hasil diskusi anggota tim peneliti setelah memperoleh informasi dari Kakandepag dan pejabat tingkat Kotamadya. Dasar pertimbangannya adalah kondisi sosial budaya masyarakat yang masih terlihat tcrtinggal bila dibandingkan dengan masyarakat wilayah kecamatan lain. Dan yang paling menonjol dari segi administrasi pemerintah adalah bahwa kecamatan ini terdiri atas 8 wilayah kelurahan dan 1 buah wilayah desa. Antara kelurahan yang satu dengan yang lain juga terdapat perbedaan yang menonjol yaitu 5 buah kelurahan bcrada di wilayah perkotaan sedang 3 kelurahan dan sebuah desa terletak di wilayah pedesaan.
Lima wilayah kelurahan perkotaan yang dimaksud adalah : Kelurahan Prapatan, Klandasan Hilir, Klandasan Hulu, Damai dan Sepingan. Tiga kelurahan pedesaan adalah kelurahan Manggar lama, Lamaru, Tritip dan desa Manggar Baru.

Dari proses penentuan wilayah penelitian sampai dengan pengumpulan data berlangsung singkat berkat bantuan dan pengaruhDrs. H. A. Muis Abdullah, Kepala Kandepag Balikpapan yang menerima dan mengantar menghadap pejabat Walikotamadya hingga ke kecamatan. Kemudian oleh kepala KUA dan Sekwilcam anggota tim diantar sampai ke kelurahan sasaran penelitian. Dengan demikian kami tidak lagi harus mengurus ijin penelitian yang bi asany a memakan waktu dan menjemukan.

Kelurahan dan desa yang kemudian menjadi sasaran perhatian dan anggota tim yang bertugas, masing-masing adalah Manggar Lama Dra. Puji Astuti, Desa Manggar Baru Drs. Zaenuddin Daulay, Kelurahan Lamaru H. Harisun Arsyad.SH dan kelurahan Tritip Drs. Rosehan Anwar. Scmentara itu ketua tim bertugas mengupulkan data kehidupan bcragama pada tingkat kecamatan melalui wawancara dan telah dokumen, juga melakukan pengamatan terhadap bimbingan pelayanan di kantor KUA dan melakukan supervisi kepada anggota tim baik secara perorangan maupun secara kclompok.

Kcgiatan supervisi terutama dimanfaalkan untuk diskusi dan tukar informasi antar sesama anggota tim dan juga untuk mengetahui hambatan yang hadapi oleh anggota. Kcscluruh proses penelitian lapangan ini berlangsung selama 3 minggu, 
yang dimulai pada tanggal 15 Juli - 5 Agustus 1991.

Mcnjelang akhir kegiatan lapangan tim juga melakukan pertemuan untuk membahas hasil-hasil yang telah diperoleh dan melakukan evaluasi. Hasil yang diperoleh dirasa telah cukup dan kemudian bersiap melakukan perpisahan dengan keluarga tempat menginap dan tak terkecuali dengan pejabat-pejabat yang banyak membantu tugas lapangan ini. Semuanya berjalan lancar, hampir-hampir tim ini tidak mengalami kesulitan termasuk persoalan hidup seharihari.

Masing-masing anggota tim setelah evaluasi terakhir melakukan kereksi dan klarifikasi data di lapangan. Setelah kembali ke Jakarta, sebagaimana kesepakatan bersama, laporan, sudah selesai pada tanggal 16 agustus 1991. Akan tetapi karena kesibukan masing-masing 1 aporan perkaus atau perkelurahan dan desa baru dapat diselesaikan pada akhir bulan Desember 1991. Atas dasar laporan inilah makalah ini disusun dengan sistematika sebagai berikut. Bagian pertama pendahuluan yang memuat temuan lapangan, konsep-konsep yang dipergunakan, penelitian di lapangan dan penulisan laporan. Bagian kedua hasil penelitian yang berisi latar belakang sosial budaya masyarakat sasaran penelitian, kehidupan sosial budaya masyarakat sasaran penelitian, kehidupan beragama dan pembahasan mengenai perubahan sosial budaya, khususnya tentang kehidupan beragama yangterjadi setelah era modernisasi. Bagian ketiga kesimpulan dan saran yang berisi beberapa kesimpulan tentang pendidikan agama, dakwah, organisasi dankepemimpi- nan, lektur keagamaan dan bimbingan pelayanan agama yang masih tetap maupun yang telah mengalami perubahan.

\section{HASIL PENELITIAN}

\subsection{Latar Sosial Budaya}

Kecamatan Balikpapan Timur yang menjadi sasaran kajian ini, sebagaimana namanya, terletak di bagian timur wilayah Kotamadya Balikpapan. Pusat pemerintahannya terletak di kelurahan Sepingan, dimana terletak pclabuhan udara yang menghubungkan wilayah propinsi Kalimantan Timur dengan wilayah propinsi yang lain, disamping pelabuhan laut di kelurahan Klandasan. Jarak pusat pemerintahan kecamatan dengan kantor Wali Kotamadya Balikpapan $4 \mathrm{Km}$, sedangkan dengan ibukota propinsi, Samarinda, berjarak 118 $\mathrm{km}$.

Transportasi dari kecamatan ini dengan kecamatan lainnya berjalan lancar, karena tersedianya kendaraan angkutan umum dalam jumlah cukup. Angkutan umum tersebut meliputi taksi, angkutan kota dengan minibus maupun kendaraan roda dua (ojek). Ongkos angkutan kota juga relatif murah. Darikantorkecamatan sampai dengan pusat kota, Pasar Balikpapan Baru, hanya dikenakan ongkos Rp 300.00, sedang dari lokasi penelitian yang terjauh, Kelurahan Tritip, yang berjarak $12 \mathrm{~km}$ dari pusat kota dikenakan biaya Rp 900,00 per orang.

Kecamatan Balikpapan Timur yang mempunyai luas $156 \mathrm{Km} 2$ membujur sepanjang pantai selat Makasar. Kendatipun demikian keadaan tanahnya pada bagian pantai datar dan berrawa-rawa, sedang pada 
bagian barat berupa perbukitan dan hutan, tenitama untuk kelurahan yang berada di wilayah luar kota. Kondisi geografis yang demikian menempatkan wilayah ini sebagai daerah yang menjadi perhatikan pemerintah daerah untuk dikembangkan sejajar dengan daerah-daerah yang lain, terutama bagi kelurahan Manggar Lama, Lamaru, Tritip dan desa Manggar Baru. Kelurahan lainnya di wilayah ini adalah Sepinggan, Damai, Kalandasan Ilir, Klandasan Ulu dan Prapatan. Lima kelurahan terakhir disebut kelurahan "dalam kota", sedangkan 4 yang pertama disebut kelurahan "luar kota". Pengertian luar kota dan dalam kota selanjutoya identik dengan kota dan desa menurut pengertian sosiologis, dan bukan dalam pengertian administratif.

Gambaran mengenai masyarakat kecamatan Balikpapan Timur dilihat dari sudut demografis adalah sebagai berikut. Pcnduduk WNI berjumlah 113.105 orang yang terdiri atas 58.253 laki-laki dan 54.852 wanita, Pcnduduk yang masih tcrgolong WNA berjumlah 1063 orang, yang sebagian besar warga negara RRC (977 orang), Eropa/ Belanda (13 orang), Taiwan (5 orang), Stateles (8 orang), lain-lain 60 orang.

Pekerjaan penduduk yang beranekaragam tentu saja memantapkan dugaan bahwa daerah ini sedang mengalami perubahan. Keragaman pekerjaan penduduk terlihat pada angka-angka sebagai berikut:

Tabel 1 : Pekerjaan Penduduk

\begin{tabular}{llrl}
\hline Petani & & 4.381 orang & $3,87 \%$ \\
Nelayan & 2.618 orang & $2,32 \%$ \\
Pengrajin & 459 orang & $0,40 \%$ \\
Buruh Perkebunan & $=$ & 543 orang & $0,48 \%$ \\
Buruh Bangunan & & 4.070 orang & $3,62 \%$ \\
Pengangkutan & $=$ & 881 orang & $0,78 \%$ \\
Buruh Pertambangan & $=$ & 1.187 orang & $1,05 \%$ \\
Pedagang & & 2.929 orang & $2,58 \%$ \\
Pegawai Negeri & 8.248 orang & $7,29 \%$ \\
ABRI & $=$ & 2.162 orang & $1,91 \%$ \\
Pensiunan & $=$ & 502 orang & $0,44 \%$ \\
\hline Jumlah & & 27.980 orang & $24,73 \%$ \\
\hline
\end{tabular}

Sumber : Data Monografi Kecamatan Balikpapan Timur 1990 
Ada beberapa keterangan sehubungan dengan pekerjaan penduduk bisa dilihat dari segi keasalan etnik. Mereka yang bekerja sebagai nelayan sebagian besar adalah suku bangsa Bugis. Pekerjaan di sektor pertanian termasuk buruh perkebunan berasal dari berbagai etnik. Namun sebagian besar mereka berasal dari orang ButondanToraja. Orang Jawa juga banyak yang menjadi petani, tetapi sangat kecil bila dibandingkan dengan populasi mereka. Pekerjaan yang banyak menarik minat orang Jawa adalah pada sektor buruh pertambangan, buruh bangunan dan pegawai negeri/ABRI. Sektor perdagangan banyak dikuasai oleh orang Cina dan Banjar untuk perdagangan menengah dan atas, sedangkan pedagang kaki lima dan pedagang kecil banyak dari kalangan orang Madura dan orang Jawa.

Selain beberapa sukubangsa yang telah disebutkan masih terdapat beberapa lagi seperti orang Kutai, Dayak, Bali, Batak, Minang dan lainnya, akan tetapi mereka ini kurang terlihat pengaruhnya dalam masyarakat. Terutama di daerah sasaran penelitian, daerah luar kota, dim ana orang Banjar, Bugis dan Jawa adalah yang paling berpengaruh dalam tata sosial budaya masyarakat. Kendatipun demikian hubungan antar golongan sukubangsa berjalan wajar dan hampir-hampir tidak pernah terjadi kasus yang berkaitan dengan masalah sukubangsa sebagaimana di wilayah Kalimantan Barat.

Kelompok-kelompok berdasarkan atas kesukubangsaan menjadi semakin nyata bila dilihat dari konsentrasi pemukiman dan juga penyelenggaraan upacara lingkaran hidup. Di daerah ini terdapat kecenderungan bahwa orang Jawa akan selalu bertempat tinggal di lingkungan mereka sendiri, begitu juga dengan sukubangsa lainnya. Dengan cara demikian mereka dapat melangsungkan kebiasaan hidup mereka baik sebagai individu maupun sebagai anggota masyarakat. Pengelompokkan berdasarkan identitas budaya sukubangsa ini menjadi tidak ditampakkan bila mereka menghadapi tugas bersama seperti membangun masjid, sekolah atau pembangunan desa lainnya.

Kebhinekaan warga masyarakat masih ditambah bagi dengan agama yang dianutnya. Kendatipun demikian corak budaya Islam masih sangat dominan. Suasana keislaman terlihat dari suara azan, pengajian, pakaian warga dan sarana keagamaan yang tersebar di seluruh wilayah. Pengaruh Islam sangat dominan disebabkan jumlah pemeluknya memang menempati posisi mayoritas sebagaimana terlihat pada tabel berikut.

Tabel 2 : Penduduk Menurut Agama 1990

\begin{tabular}{|l|r|r|}
\hline Agama & \multicolumn{1}{|c|}{ Jumlah } & \multicolumn{1}{c|}{$\%$} \\
\hline Islam & 100.647 & 89,82 \\
Kristen & 6.168 & 5,53 \\
Katolik & 3.075 & 2,76 \\
Hindu & 543 & 0,48 \\
Budha & 1.499 & 1,34 \\
Lain-lain & 42 & 0,03 \\
\hline Jumlah & 111.374 & 100,00 \\
\hline
\end{tabular}

Sumber: Laporan Tahunan KUA Kec. Balikpapan Timur 1990

Pemeluk agama non Islam tersebut sebagian besar berada di wilayah kelurahan

No. 7 \& 8 Th. EI Juli / Desember 1992 
"dalam kota", di wilayah "luar kota" juga terdapat pemeluk agama non Islam namun jumlah sedikit sekali, kecuali di Kelurahan Lamaru terdapat komunitas Kristen orang Toraja yang tinggal di daerah bukit. Komposisi penduduk berdasarkan agama yang dipeluk seperti pada tabel 2 dapat menggam barkan betapa Islam berpengaruh pada kehidupan sosial budaya masyarakat setempat. Akan tetapi dalam kenyataannya sebagaimana akan dijelaskan dalam sub bab berikut tidaklah demikian.

\subsection{Kehidupan Beragama}

Diskripsi tentang kehidupan beragama dalam tulisan ini, sebagaimana maksud dan tujuan penelitian, dibatasi pada masalah pendidikan, dakwah, organisasi dan kepemimpinan, lektur keagamaan, dan bimbingan pelayanan keagamaan. Kelima persoalan tersebut selanjutnya akan dilihat dalam kaitannya dengan perubahan-perubahan (transformasi) yang terjadi dewasa ini baik yang menyangkut perubahan pada segi kultur maupun struktur sosial di daerah kelurahan "luar kota".

Pendidikan agama di sekolah dimulai sejak klas 1 SD sampai dengan kelas tertinggi. Menurut kurikulum 1984, jumlah jam pelajaran untuk kelas 1-3 perminggu 2 jam pelajaran dan untuk kelas 4-6 pelajaran agama diberikan 3 jam pelajaran. Ketentuan ini dilaksanakan sebagaimana mestinya, meskipun demikian hasil evaluasi guru menunjukkan target yang harus dicapai baru sekitar 50\% (Manggar Baru) dengan daya serap murid yang rendah terutama untuk membaca dan menulis Al Quran (30\%) untuk Manggar Baru dan Tritip. Untuk mengatasi kekurangan ini guru agama mengambil inisiatif menyelenggarakan les di luar jam pelaj aran. Pencapai an target kurikulum yang tertinggi terdapat pada SD Manggar, yakni $80 \%$, kekurangannya (20\%) diusahakan dapat dicapai melalui penugasan yang bersifat perorangan maupun kelompok.

Rendahnya daya serap dan sulitnya guru mencapai target kurikulum disebabkan oleh banyaknya beban atau materi pokok bahasan, di samping pokok bahasan yang mengulang-ulang. Faktor ekonomi orang tuajugaberpengaruhpadakekuranganmampuan anak menangkap materi pelajaran. Anak-anak itu sepulang dari sekolah masih harus membantu orang tua mencari nafkah. Akibatnya berkembang ungkapan bahwa belajarbekerjajauhlebihbergunadibanding dengan bersekolah, karena sekolah tidak dapat menjamin seseorang dapat memperoleh pekerjaan yang layak.

Kondisi sosial ekonomi yang kurang menguntungkan juga berakibat pada pergeseran pandangan sebagian orang tua tentang sekolah agama (madrasah). Pada awal orde baru (1967) di desa Manggar Baru berdiri sebuah madrasah diniyah. Kemudian pada tahun 1973 diresmikan sebagai madrasah Ibtida'iyah dan Tsanawiyah. Sejak tahun 1976 jumlah muridnya terus menurun. Begitu juga yang terjadi untuk madrasah sejenis di Manggar Lama. Perbedaan terjadi pada masyarakat kelurahan Lamaru dan Tritip. Masyarakat Lamaru justru sedang merintis berdirinya madrasah dan di Tritip madrasah, terutama Hidayatullah berkembang dengan baik. Sebenarnya selain masalah ekonomi yang menjadi sebab mundurnya madrasah, karena kesulitan 
dalam memperolch lapangan kerja, juga disebabkan olch masuknya guru agama lulusan pcsantren Hidayatullah yang oleh masyarakat setempat dipandang beraliran baru (kaum muda).

Pesantren Hidayatullah (PH) kantor pusatnya di Kampung Bugis Kota Balikpapan memiliki pusat pendidikan dan latihan di kelurahan Tritip, Gunung Tembak. Olch masyarakat setempat pemimpin dan santri PH dipandang sebagai penganut dan penyiar faham baru yang dilawankan dengan "kaum tua" Kchadiran PH di wilayah ini sangat berpengaruh tcrhadap pendidikan agama di dalam masyarakat, dakwah dan juga ke-pemimpinan serta organisasi keagamaan.

Dakwah, pendidikan agama dalam masyarakat, mcmpcroleh scmangat baru dengan munculnya faham baru. Selain PH juga berkembang Lembaga Karyawan Islam (Lemkari), sekarang bcrubah lagi menjadi LDII (Lembaga Dakwah Islam Indonesia). Sebelum munculnya faham baru dakwah Islam bcrlangsung mclalui khutbah Jumat, peringatan hari besar Islam, pengajian majlis taklim, pengajian anakanak atau remaja scmata-mata mengikuti cara-cara yang telah be rlangsung lama. Cara lama yang dimaksud adalah dahulu khutbah dengan bahasa Arab, sekarang dengan bahasa Indonesia. Pengajian dilakukan dengan pendengar yang pasif. Scbaliknya LEMKARI dan PH dalam bcrdakwah mcnggunakan metode diskusi dan bahkan kerja nyata untuk moningkatkan taraf hidup masyarakat sebagaimana yang dikembangkan oleh PH di Gunung Tembak, Tritip.

Hasil yang dapat dilihat oleh peneliti adalah bahwa kehidupan beragama di wilayah ini semakin meningkat baik dari segi kualitas maupun kuantitas. Dari segi kuantitas kehidupan beragama berkembang dari jumlah sarana peribadatan kelompok pengajian yang pada tahun 1970 an masih sangat terbatas, setiap kelurahan hanya ada 1-2 masjid/musalah, sekarang setiap perkampungan sudah memiliki sarana ibadah dengan kelompok pengajian baik untuk laki-laki, wanita, remaja maupun anakanak. Dari segi kualitas terlihat gejala kehidupan beragama yang semakin mengarah pada pclaksanaan ajaran agama yang bercorak "pemurnian" dan meninggalkan scmangat "tradisional", khususnya untuk Tritip dan Lamaru, sedang untuk Manggar dan Manggar Baru justru terlihat gejala pergcrseran nilai kearah "scrba boleh".

Bcrpcdaan corak kehidupan beragama tersebut disebabkan didua wilayah Manggar sekarang ini sedang berkembang menjadi bagian perkotaan yang ditandai dengan munculnya tempat-tempat hiburan seperti arena rckreasi pantai, tempat bilyard, bioskop disamping hubungan transportasi yang lancar ke kota sampai dengan larut malam. Sebaliknya kedua wilayah lainnya masih tergolong jauh dengan pusat rckreasi dan kota, apalagi bila waktu malam. Di samping itu peranan pemimpin agama di Tritip dan Lamaru jauh lebih berwibawa, terutama pemimpin pesantren Hidayatullah yang pada tahun 1984 berhasil mcmpcroleh penghargaan nasional berupa "Kalpataru", untuk pcnyelamatan lingkungan hidup.

Kepemimpinan di lingkungan masyarakat Islam, sebagaimana dikemukakan oleh Taufik Abdullah, ada tiga macam. Pcrtama pern impin formal (pejabat), kedua pemimpin 
organisasi dan ketiga pemimpin ulama (kyai). Antara pemimpin tipe pertama dengan pemimpin tipe ketiga dipertentangkan sebagai struktur pejabat versus pemimpin anti struktur (1980:20). Pada masyarakat sasaran penelitian ketiga tipe kepemimpinan tersebut berjalan saling melengkapi tanpa ada pertentangan. Pertentangan justru timbul pada tingkat kepemimpinan ulama yang sedang memperebutkan pengaruhnya, seperti terungkap pada penggolongan "kaum muda" dan "kaum tua". Beberapa tahun terakhir setelah munculnya faham baru yang terorganisir (Lemkari dan PH) masyarakat seakan-akan terbclah dua, akan tetapi berkat adanya keterlibatan tokoh muda, Penyuluh Agama Honorer (PA) yang aktif membina organisasi remaja mesjid, perbedaan faham tersebut dapat diakomodir. Begitujugaperan an pemimpin formal, yang dalam masyarakat sedang berkembang menduduki posisi lebih tinggi, berhasil mengontrol perkembangan faham dan organisasi keagamaan untuk lebih bcrsifat akomodatif.

Lemahnya posisi pemimpin informal, pemimpin organisasi dibanding dengan pemimpin formal juga terlihat pada peranan bimbingan dan pelayanan keagamaan dalam masyarakat. Kalau bimbingan dan pelayanan keagamaan yang bersifat hari an warga masyarakat dapat memperolehnya melalui pemimpin agama setempat, maka untuk kepentingan peringatan hari besar Islam mereka mengundang pejabat KUA atau KANDEPAG untuk memberikan bimbingan. Begitu juga dalam kaitannya dengan pembangunan sarana peribadatan atau keagamaan lainnya ketergantungan kepada peranan pejabat formal masih sangat tinggi. Foktor pendukung utama keterikatanwargamasyarakatterhadap pemimpin pejabat adalah karenapersoalandana. Dalam penyelenggaraan Taman Pendidikan Al Qur'an misalnya, mereka mondapat penataran dengan memperoleh uang saku. Menjadi penyuluh agama juga mendapat honor bulanan dan apalagi bila ulama setempat dilugaskan sebagai imam penghulu (P3NTCR) tentu sangat terikat dengan pejabat agama di atasnya.

Di samping memiliki dana, pemimpin pejabat, dalam hal ini kepala KUA dan staf juga aktif terjun ke masyarakat memberikan penyuluhan dan bimbingan tidak hanya yang menyangkut bidang tugasnya juga dalam kegiatan pembangunan yang lebih luas. Penyuluhan dan penerangan apa saja yang dilaksanakan oleh pemerintah tingkat kecamatan maupun tingkat kotamadya selalu melibatkan KUA atau KANDEPAG.

Aparat KUA dalam kegiatan sehari-hari melaksanakan tugas sebagaimana dalam KMA No 18/1975, disamping itu juga memberikan bimbingan dan pelayanan untuk keluarga bahagia kepada mereka yang akan menikah. Penyuluhan ini dikaitakan dengan penyuluhan Keluarga Bcrencana. Selain itu kepala KUA juga menyelenggarakan penasehatan dan penyelesaian perceraian sebelum yang bersangkutan ke Pengadilan Agama. Di luar tugas tersebut kepala KUA juga dilibatkan dalam berbagai kegiatan pembangunan di wilayah ini tidak saja yang menyangkut pembangunan bidang agama, tetapi pembangunan dalam arti luas. Selain KUA, aparat Departemen di wilayah kecamatan adalah Penilik Pendidikan 
Agama (PPA). Instansi ini berkantor dan mcnumpang di KUA Kec. Aparatnya hanya scorang, tanpa staf tetapi tugas kepenilikan meliputi lebih dari seratus sekolah. Oleh karena itu bimbingan dan pelayanan dilakukanmclalui rapat-rapatdinas. Hasil yang dicapai melalui usaha ini adalah masingmasing guru dapat membuat rencana kegiatan belajar mengajar (SATPEL).

Perkembangan kehidupan bcragama lainnya sebagai dampak masuknya faham baru adalah munculnya literalur-literatur yang scmakin bcragam. Kalau dahulu pcmuka-pcmuka agama hanya mcngoleksi kitab-kitab bcrbahasa Melayu seperti kitab Pcrukunan dan kitab Berzanji, Yasin, kitab Khotbah yang juga berbahasa Melayu, sckarang mereka telah banyak mcngoleksi kitab-kitab terjemahan. Hanya saja bagi mereka yang masih menganut faham "kaum tua", kitab-kitab yang mereka baca adalah yang tidak bertentangan dengan fahamnya. Scbaliknya penganut faham "kaum muda", kitab-kitab yang-mereka baca sudah meliputi hampir semua kitab terkenal seperti Fiqh Sunah, Naitul Autar, Bidayatul Mujtahid dalam bidang fikih dan kitab-kitab modern dalam ilmu pertanian, ilmu sosial dan polilik yang tersedia dalam perpustakaan Pesantrcn Hidayatullah.

Perubahan kehidupan beragama tersebut menunjukkan bahwa faktor penyebab utama adalah masuknya pembaharu. Tokoh utama yang bcrhasil menanamkan pengaruh pembaharuan hidup beragama adalah ustaz Abdullah Said. Usahanya melalui pesantren Hidayatullah yaitu belajar agama sambil hidup secara komunal dan membiay ai semua kegiatan keagamaan dengan kerja kreatif (amal saleh) merupakan contoh kongkrit pembentukan sebuah komuniti keagamaan yang solid. Di sini ulama (ustaz) bukan sekedar makalelar kebudayaan tetapi sebagai inovator (bandingkan dengan Hirokoshi, 1987). Karya nyata ulama ini selain mendapat penghargaan pemerintah pusat juga menjadi saksi dan ekaligus acuan bagi masyarakat sekitarnya untuk meningkatkan pertanian dengan mcmanfaatkan teknologi maju.

Keberhasilan peningkatan taraf hidup masyarakat pesantren Hidayatullah dalam sebuah jemaah yang dilandasi semangat mclaksanakan agama dengan sebaikbaiknya rupanya ingin disebarluaskan ke wilayahdi luarpcsantren.Tentu sajagerakan ini mendapat reaksi dari tokoh agama yang kemudian menamakan "kaum tua" dan untuk sementara waktu terjadi prasangka dan pcrtentangan. begitu juga perubahan cara mcmahami agama yang ditampilkan oleh Lemkari, bcrakibat pada semakin beragamnya pengamalan agama (Islam) di wilayah ini disamping scbab masuknya pendatang baru yang berasal dari berbagai sistem sosial budaya lain.

\section{PENUTUP}

\subsection{Kesimpulan}

Konfigurasi dan transformasi kehidupan agama di wilayah ini dapat dicirikan sebagai berikut. Kehidupan beragama pada kalangan masyarakat yang dekat dengan wilayah perkotaan (Manggar lama dan Manggar baru) sedang mengalami pergeseran nilai berkenaan dengan pandangan tentang sekolah agama. Pada saat ini se- 
bagian warga masyarakat memandang sekolah umum lebih memberi peluang untuk memperoleh pekerjaan bila dibandingkan dengan sekolah agama setelah mereka tamat. Selain itu terdapat kecenderungan pergeseran nilai keagamaan yang mengarah kepada "serba boleh" yang berkaitan dengan nilai-nilai moral.

Kendatipun demikian pendidikan agama yang dilakukan di luar sekolah tctap berjalan. Pendidikan ini dimaksudkan untuk menambah pengetahuan agama anak yang tidak mungkin dapat diperolehnya dari sekolah. Pendidikan agama di sekolah ternyata kurang dapat diserap anak secara baik karena alokasi waktu, jumlah pokok bahasan yang padat dan pengulangan materi. Terutama untuk pendidikan membaca dan menulis Al Quran, sangat tidak mungkin dapat diperoleh di sekolah umum.

Sebaliknya kehidupan beragama di dua kelurahan yang jauh dari wilayah perkotaan justru cenderung semakin monunjukkan menguatnya nilai-nilai kesalchan dan ketaatan beragama. Sekolah agama dan pengajian anak-anak serta remaja berkembang dan begitu jugakegiatanmajlis taklim. Faktor penyebab pcrubahan adalah munculnya pemimpin keagamaan yang berorientasi ke masa depan. Kepemimpinan dalam masyarakat bcragamajugamengalami diversifikasi dari kepemimpinan lama (imam), kepada pemimpin faham keagamaan, pemimpin organisasi dan pemimpin pejabat.

Seiring dengan munculnya faham baru, bebcrapa pranata keagamaan menjadi berubah. Azan Jumat scmula dua kali, untuk bebcrapa masjid menjadi sckali. Khotbah dahulu dengan bahasa Arab, diganti dengan bahasa Indonesia. Lektur keagamaan juga mengalami pengayaan dengan masuknya kitab-kitab yang tergolong maju (tajdid). Dakwah yang menolong diganti dengan dialog. Tentu saja perubahan-perubahan tersebut tidak begitu saja dapat diterima. Pertentangan antara pendukung kebudayaan lama "kaum tua" melawan "kaum muda" acapkali terjadi dan masih bersifat laten. Upaya pcnyelesaian pertentangan antara lain dapat dilakukan sendiri oleh para pemuda yang berhimpun dalam organisasi Ikatan Remaja Masjid dan juga oleh pemimpin pejabat.

Peranan pemimpin pejabat dalam bimbingan dan pelayan meliputi bidang tugas sebagaimana diatur dalam KMA No 18/ 1975 pasal 729 dan pasal 730 . Selain itu juga memberikan pelayanan konsultasi masalah pcrceraian, keluarga berencana, kesejahteraan keluarga dan warisan. Di luar kantor aparat KUA melaksanakan bimbingan dan pelayanan berkaitan pembangunan dalam arti luas.

\section{3,2. Rekomendasi}

Sejalan dengan kesimpulan di atas, rekomendasi yang dapat disampaikan dalam kaitannya dengan bimbingan dan pelayanan keagamaan adalah sebagai berikut. Pertama, pemerintah (Dcpartemen Agama dan Pemda) setempat perlu mempertimbangkan perlunya mengangkat Pcsantren Hidayatullah sebagai pusat pengembangan pcrtanian, perlukangan dan perikanan dan peternakan bagi masyarakat Islam di sekitarnya tanpa mereka harus mengikuti faham keagamaan yang dianut oleh pemimpin pcsantren. 
Saran tersebut dikemukakan didasarkan atas kenyataan bahwa persoalan utama yang dihadapi oleh warga masyarakat di daerah ini adalah peningkatan kemampuan ekonomi, melalui upaya ini diharapkan mereka dapat meningkatkan taraf hidupnya, termasuk kehidupan beragama. Pada sisi lain pesantren Hidayatullah telah terbukti berhasil mengembangkan pertanian, peternakan dan perikanan,

Kedudukan dan peranan pemimpin pejabat (KUA dan DEPAG) yang secara sosial berada di atas golongan kepemimpinan lainnya mampu mengerahkan potensi yang dimiliki oleh warga masyarakat untuk berkembang dan sekaligus dapat meng- hindari dampak negatif modernisasi. Upaya yang dapat dilakukan antara lain dengan meningkatkan jumlah Penyuluh Agama Honorer (PAH) dan profesionalisme melalui penataran dan pelatihan. Pada posisi yang sama, PPA juga perlu dukungan tenaga staf dan anggaran yang memadai. Masalah pertentangan faham sedapat mungkin dapat dikendalikan melalui lembaga keagamaan yang sudah ada (MUI), karena masingmasing golongan diwakili dalam lembaga ini. Fungsi aparat Depag dalam hal ini adalah mengkoordinasikan serta memberikan fasilitas sebagaimana yang telah berlangsung selama ini. 


\section{DAFTAR BACAAN}

Abdullah, Taufik "Pola Kepemimpinan Islam di Indonesia : Tinjauan Umum", dalam Prisma, 8 Juni 1982.

Benedict, Ruth Pattern of Culture. New York, Houghton Mi fflin Company (Edisi ke delapan). 1959

Forter, Goerge M Traditional Societies and Tecknological Change. New York. Harper \& Row Publishers (Edisi kedua). 1973

Horikoshi, Hiroko Kyai dan Perubahan Sosial. Jakarta, PenerbitP3M (terj. Umar Basahin dan Andi Muarly Sunrawa). 1987

Kuntowijoyo Budaya dan Masyarakat. Yogyakarta, Penerbit, Tiara Wacana. 1987

1991 Paradigma Islam : Interpretasi Untuk Aksi. Bandung, Penerbit Mizan.
Sajogya "Kata Pengantar", dalam C. Geertz Involusi Pertanian Indonesia. Jakarta, Penerbit Bhratara (Terj. S. Supomo). 1983

Splindler, Louise Culture Change and Modernization : Mini Model and Case Studies. Illinois, Waverland, Press, Inc. 1984

Suwarsono \& Alvin Y. So Perubahan Sosial Dan Pembangunan di Indonesia. Jakarta, Penerbit LP3ES. 1991

Spradley, J P \& David W. Curdy "Kcbudayaan dan Pembangunan" dalam Dialog No.21 Tahun XI. 1975

Syafi'i, Ahmad Rangkuman Penelitian Konfigurasi dan Trans Formasi Kehidupan Agama. Jakarta, Penerbit Badan Litbang Agama Depag. 1991 